
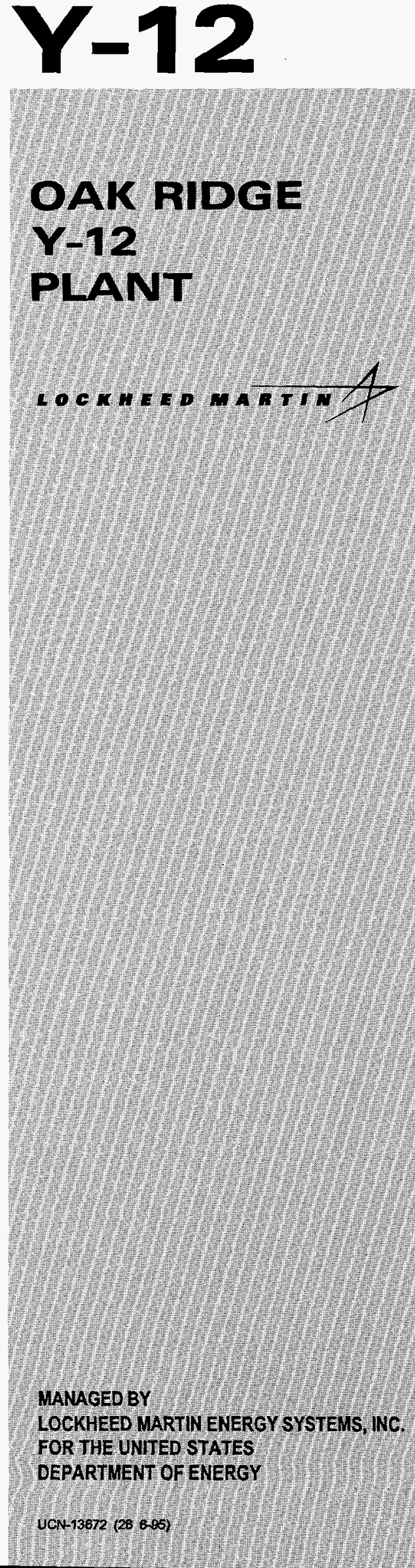

Project Accomplishment Summary for Project Number 91-Y12P-073-A1

\title{
MACHINE TOOL EVALUATION AND MACHINING OPERATION DEVELOPMENT
}

T. O. Morris

Lockheed Martin Energy Systems, Inc.

Dr. Richard Kegg

Cincinnati Milacron Marketing Company

March 15, 1997

Approved for Public Release; distribution is unlimited.

\author{
Prepared by the \\ Oak Ridge Y-12 Plant \\ managed by \\ LOCKHEED MARTIN ENERGY SYSTEMS, INC. \\ for the \\ U.S. DEPARTMENT OF ENERGY \\ under contract DE-AC05-84OR21400 \\ DITIBUTION OP TMIS DOCUMRTI IS UNLMMTED

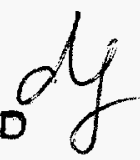




\section{DISCLAIMER}

This report was prepared as an account of work sponsored by an agency of the United States Government. Neither the United States Government nor any agency thereof, nor any of their employees, makes any warranty, express or implied, or assumes any legal liability or responsibility for the accuracy, completeness, or usefulness of any information, apparatus, product, or process disclosed, or represents that its use would not infringe privately owned rights. Reference herein to any specific commercial product, process, or service by trade name, trademark, manufacturer, or otherwise does not necessarily constitute or imply its endorsement, recommendation, or favoring by the United States Government or any agency thereof. The views and opinions of authors expressed herein do not necessarily state or reflect those of the United States Government or any agency thereof. 


\section{DISCLAIMER}

Portions of this document may be illegible electronic image products. Images are produced from the best available original document. 


\section{PROJECT ACCOMPLISHMENT SUMMARY}

Title:

Machine Tool Evaluation and Machining Operation Development

DOE TTI Number: 91-Y12P-073-A1

CRADA Number: Y1291-0136

Partner:

Cincinnati Milacron

\section{BACKGROUND}

Finish machining operations contribute the majority of the costs associated with fabricating high quality products from ceramic materials and other difficult to machine materials. These components are typically used in harsh environments such as diesel engines, the defense industry, and automotive applications. The required finishing operations involve the evaluation and improvements in a variety of technology areas including the machine tool, cutting tool materials, machining fluids, component grinding methods and component certification methods. The broad range of manufacturing problem solving expertise available in Oak Ridge provided resources that were far beyond what was available to Cincinnati Milacron. Cincinnati Milacron contributed equipment, such as machine tools, grinding wheels, and machining fluids plus operation-specific experience that allowed Oak Ridge personnel to significantly expand their knowledge and experience base. In addition, addressing these challenging tasks enabled Oak Ridge personnel to maintain familiarity with rapidly advancing technologies, such as those associated with machine tools, new grinding wheels and grinding fluids as well as the resulting environmental problems involved with the utilization of some of there products.

\section{DESCRIPTION}

The purpose of this CRADA was to support Cincinnati Milacron's needs in fabricating precision components, from difficult to machine materials, while maintaining and enhancing the precision manufacturing skills of the Oak Ridge Complex. Oak Ridge and Cincinnati Milacron personnel worked in a team relationship wherein each contributed equally to the success of the program. Process characterization, control technologies, machine tool capabilities, and environmental issues were the primary focus areas. In general, Oak Ridge contributed a wider range of expertise in machine tool testing and monitoring, and environmental testing on machining fluids to the defined tasks while Cincinnati Milacron personnel provided equipment, operationsspecific knowledge and shop-floor services to each task. Cincinnati Milacron was very pleased with the results of all of the CRADA tasks. However, some of the environmental tasks were not carried through to a desired completion due to an expanding realization of need as the work progressed. This expansion of the desired goals then exceeded the time length of the CRADA. Discussions are underway on continuing these tasks under either a Work for Others agreement or some alternate funding.

\section{BENEFITS TO DOE}

This CRADA, and others like it, enabled Oak Ridge personnel to maintain critical process control skills with up to date equipment and to be ready to apply these skills in support of the Advanced Design and Production Technologies (ADaPT) Program. Specifically, the machine 
tool monitoring, operation analysis, and general skills that have been maintained through this CRADA can be used in the Agile Production Operations portion of Y-12's ADaPT program. In addition environmental compliant manufacturing is of interest to all who machine any metal, ceramic or composite materials. EPA requirements, federal and local government regulations, and public insistence on compliance are all becoming more stringent and demanding. This is a trend that is unlikely to change in the future. We are all going to have to be more aware of these requirements and more attentive to meeting the legal and civic obligations whether we are a large manufacturing concern such as a DOE contractor, or a small local machine shop.

Every machine shop whether it manufactures metal brackets or weapons parts uses machining fluids as a lubricant and/or coolant. The use and more importantly the disposal of this fluid (either contaminated or uncontaminated) is of primary importance if one is to remain in compliance. This fluid in an ideal situation would originally be composed of constituents that can be easily disposed of (ideally down the sanitary disposal system) when it reaches the end of its useful life. In order to minimize the frequency of disposal the coolant should be recyclable through some filtration or centrifuge process. There should be some method of determining when a fluid should be recycled. The fluid would need to be recycled if it became contaminated with "tramp oil" from the machine lubrication system, or if the bacterial growth in the fluid got out of control. Prompt action in such cases is mandatory to avoid the necessity of immediate disposal. When new fluid is added to the machine's coolant tank, it contains a biocide to help deter the growth of bacteria and possibly other ingredients. The biocide and other ingredients are not always compatible with the good health of those in the immediate area of the operation such as the machinist. Therefore there needs to be a method of detecting airborne mists which might be inhaled or even deposited on the skin to cause dermatitis. The magnitude of the machining fluid problem is very large, interconnected, and difficult to solve without a sizable effort, but the affect of achieving a solution is very rewarding to everyone large or small private or governmental.

\section{ECONOMIC IMPACT}

The commercial impact has been very promising for Cincinnati Milacron. The improvements to their Avenger lathe and Sabre vertical spindle grinding machine have resulted in a number of commercial sales of these type machines. Data suggesting the vast improvements in capabilities obtained in grinding ceramic materials at high grinding speeds helped Cincinnati Milacron to develop an entirely new centerless grinder (the Viking) which has this high speed capability and has incurred much market place interest. Such success in the market place enhances their ability to successfully compete against international competitors in the machine tool market. The testing and improvements in vitrified bond diamond grinding wheels have resulted in sales in the budding ceramic component manufacturing community, which has the potential to become significant in the future. Results of machining fluid related tasks have not been realized as of this time but again Cincinnati Milacron firmly believes that they will result in a significant economic impact in the future.

\section{PROJECT STATUS}

This project has been completed and the final report is being prepared with the one exception of the waste disposal task for machining fluids, which was funded by ER-DOE and is being continued in FY97. 
DOE FACILITY POINT(S) OF CONTACT FOR PROJECT INFORMATION:

T.O. Morris

Lockheed Martin Energy Systems, Inc.

P.O. Box 2008

Building 4515, Mail Stop 6069

Oak Ridge, TN 37831

Phone 423 241-2796

FAX 423 574-4913

INDUSTRIAL CONTACT

Dr. Dick Kegg

Vice President

Cincinnati Milacron

4701 Marburg Avenue

Cincinnati, OH 45209

Phone 513 841-8594

\section{PROJECT EXAMPLES}

At this time, there are no project examples that the partners are ready to release.

\section{TECHNOLOGY COMMERCIALIZATION}

Results of this project still have potential market advantage to Cincinnati Milacron and involve business sensitive issues. 


\section{Distribution List:}

T.O. Morris, Bldg. 4515, MS 6069

D.W. Post, Bldg. 9202, MS 8097

Ray Ford, MS 8084, 9203

Andy Stevens/DOE OR, MS 8009, 9704-2

Diane Bird, DOE DP-17 [DOE-HQ]

Bill Wilburn, MS 8015, 9704-2

Y-12 Central Files, MS 8169, 9711-5 (3 copies)

Dr. Richard Kegg, Vice President, Cincinnati Milacron, 4701 Marburg Avenue, Cincinnati, OH 45209 (5 copies) 